Jurnal Kependudukan Indonesia | Vol. 12 No. 1 Juni 2017 | 39-54

JURNAL KEPENDUDUKAN INDONESIA

p-ISSN : 1907-2902 (Print)

e-ISSN : 2502-8537 (Online)

\title{
PENGAMBILAN KEPUTUSAN TENAGA KERJA INDONESIA (TKI) \\ PEREMPUAN UNTUK BEKERJA DI LUAR NEGERI: KASUS KABUPATEN CILACAP
}

\section{(DECISION MAKING TO WORK OVERSEAS AMONG INDONESIAN WOMEN LABOR MIGRANTS: THE CASE OF CILACAP DISTRICT)}

\author{
Aswatini Raharto \\ Pusat Penelitian Kependudukan - LIPI \\ Korespondensi Penulis: tiniaswa2710@gmail.com
}

\begin{abstract}
In the past, women migrants are considered as passive migrants following their parents or husbands. However, the increasing number of Indonesian women migrating to work abroad, even outnumbering men, suggests the importance of understanding the reasons underlined their movements. This article examines the decision-making process of working abroad among the returned Indonesian women migrants. A quantitative approach was used to analyze secondary data from several government institutions. Also, the qualitative approach was utilized to understand the migration decision-making process. The study was conducted in Cilacap District, one of the major labor migrant sending districts in Indonesia. The result showed that women have no other choice than working abroad, mainly due to the economic reason. Moreover, the initiative to work abroad commonly comes from the women themselves, while other family members, especially father and husband, only give their consent. It can be said that women are more autonomous and self-assured when deciding to work abroad.
\end{abstract}

Keywords: Labor Migration, Women, Cilacap, Decision Making

\begin{abstract}
Abstrak
Pada awalnya, migran perempuan hanya dianggap sebagai pengikut orang tua atau suami. Namun, meningkatnya arus migrasi tenaga kerja perempuan Indonesia ke luar negeri, bahkan melebihi laki-laki, menunjukkan pentingnya pemahaman tentang alasan perpindahan mereka. Tulisan ini membahas proses pengambilan keputusan TKI perempuan purna. Pendekatan kuantitatif digunakan untuk menganalisis data sekunder dari berbagai lembaga terkait. Selain itu, pendekatan kualitatif dilakukan untuk memahami proses pengambilan keputusan migrasi. Kajian dilakukan di Kabupaten Cilacap, salah satu kabupaten utama pengirim TKI ke luar negeri. Hasil analisis menunjukkan bahwa perempuan tidak memiliki pilihan selain bekerja di luar negeri, terutama karena pertimbangan faktor ekonomi. Inisiatif untuk bekerja umumnya datang dari perempuan sendiri, sedangkan anggota keluarga terutama ayah dan suami hanya memberikan persetujuan. Dengan demikian, perempuan sudah lebih memiliki kebebasan dan kepercayaan diri untuk memutuskan bekerja di luar negeri.
\end{abstract}

Kata Kunci: Migrasi Pekerja, Perempuan, Cilacap, Pengambilan Keputusan 


\section{PENDAHULUAN}

Pada tahun 2015, kira-kira 244 juta orang (sekitar 3,3 persen) penduduk dunia tinggal di luar negara kelahirannya, meningkat dari sekitar 2,8 persen pada tahun 2000 (United Nations [UN], 2016). Kondisi ini menunjukkan bertambah pentingnya fenomena migrasi internasional yang sudah menjadi bagian integral dari kehidupan ekonomi dan sosial penduduk dunia. Faktor ekonomi, untuk mencari pekerjaan dan kehidupan yang lebih baik merupakan salah satu alasan penting dalam migrasi ini, selain alasan yang terkait dengan keamanan (konflik sosial, kekacauan politik) yang menyebabkan seseorang atau keluarga meninggalkan negaranya untuk mengungsi ke negara lain yang dianggap dapat menjamin keamanan (Hugo, 2004). Indonesia dikenal sebagai negara kedua, setelah Filipina, dalam besaran migrasi tenaga kerja untuk bekerja di luar negaranya, diantara negara-negara ASEAN (International Labour Organization [ILO], 2015).

Sudah banyak dikemukakan dalam literatur dan studistudi terdahulu bahwa dalam proses migrasi, perempuan pada umumnya adalah migran pasif yang bermigrasi karena mengikuti orang tua (ayah), suami ataupun saudara laki-lakinya (Suharso dkk., 1976; Fawcett \& De Jong, 1981; Aswatini, 2002; Boyd \& Grieko, 2003; Hugo, 2004). Dalam konteks migrasi tenaga kerja Indonesia (TKI) perempuan, sejak tahun 1980 -an proporsi perempuan yang bermigrasi untuk bekerja di luar negeri sudah cukup besar (UN-ESCAP \& UN-ECSWA, 2013). Data pengiriman TKI pada beberapa periode waktu menunjukkan bahwa proporsi TKI perempuan yang dikirim ke luar negeri lebih besar daripada laki-laki. Ini dapat dilihat dari rasio jenis kelamin ${ }^{1}$ sebesar 47,5 pada periode 1989-1994, 36 pada periode $1994-2008$, dan sebesar 77,6 pada periode 2013-2015 (Hugo, 1995, Tabel 4; UN-ESCAP \& UNECSWA, 2013, Tabel VI.2). Keadaan ini menunjukkan bahwa ada kecenderungan migrasi TKI perempuan tidak tergantung kepada migrasi anggota keluarga lakilaki. Perempuan juga merupakan migran aktif yang bermigrasi sendiri untuk bekerja di luar negeri. Ini juga menjadi pertanda adanya feminisasi migrasi TKI karena jumlah TKI perempuan yang bekerja di luar negeri secara total mengalami peningkatan melebihi laki-laki.

Konstruksi sosial yang selama ini dipahami menempatkan perempuan dalam domain rumah tangga dengan tugas utama kegiatan-kegiatan terkait dengan mengurus rumah tangga dan anak. Sebaliknya, laki- laki lebih ditempatkan pada domain di luar rumah tangga dengan fokus pada kegiatan-kegiatan ekonomi produktif yang menghasilkan pendapatan, sesuai dengan peran yang diharapkan sebagai kepala rumah tangga dan pencari nafkah utama. Karena itu, keterlibatan perempuan dalam kegiatan-kegiatan ekonomi yang berpenghasilan, yang dalam konteks migrasi TKI perempuan sebagai pekerja migran luar negeri, menunjukkan bahwa domain kegiatan perempuan sudah meluas pada kegiatan-kegiatan ekonomi di luar rumah tangga. Calon TKI perempuan harus mempertimbangkan pilihan-pilihan antara mengurus rumah tangga saja, bekerja di dalam negeri, dan bekerja di luar negeri sebagai TKI migran. Bekerja di luar negeri juga melibatkan pertimbangan negaranegara tujuannya. Oleh karena itu, kondisi ini menjadi hal yang penting untuk dipahami.

Mengacu pada kecenderungan perubahan dalam fenomena migrasi TKI, tulisan ini membahas proses pengambilan keputusan dalam migrasi TKI perempuan untuk bekerja di luar negeri untuk mendapatkan pemahaman tentang faktor-faktor yang berpengaruh dan mendasari perubahan yang terjadi. Naskah ini ditulis berdasarkan studi yang dilakukan dengan pendekatan kuantitatif dan kualitatif di Kabupaten Cilacap, yang terletak di pantai selatan Provinsi Jawa Tengah (Gambar 1).

\section{Gambar 1. Kabupaten Cilacap, Jawa Tengah}

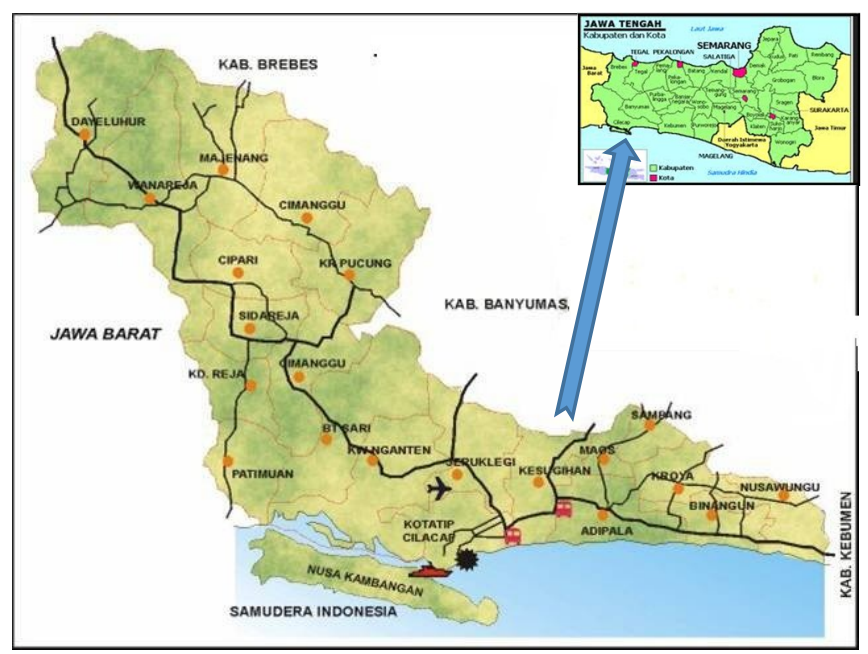

Sumber:

https://www.kudminosaroyocilacap.com/infopublic/daftar-desakelurahan-kecamatan-sertakodepos-di-kotakabupaten-cilacap-jawa-tengahjateng/

\footnotetext{
${ }^{1}$ Rasio jenis kelamin: jumlah laki-laki per 100 perempuan.
} 
Provinsi Jawa Tengah dikenal sebagai provinsi kedua setelah Jawa Barat dalam jumlah TKI yang dikirim ke luar negeri. Di Provinsi Jawa Tengah, pada tahun 2016 Cilacap merupakan kabupaten pengirim TKI terbesar dengan proporsi sebesar 19,3 persen dari total pengiriman TKI, diikuti oleh Kabupaten Kendal (12,9 persen) dan Kabupaten Brebes (8,7 persen) (Pusat Penelitian Pengembangan dan Informasi Badan Nasional Penempatan dan Perlindungan Tenaga Kerja Indonesia [BNP2TKI], 2016a).

Pendekatan kuantitatif diaplikasikan untuk mendapatkan pemahaman tentang kecenderungan dan arus pengiriman TKI berdasarkan data sekunder dari berbagai sumber. Pendekatan kualitatif diaplikasikan untuk memahami proses pengambilan keputusan di kalangan TKI perempuan untuk bekerja di luar negeri, berdasarkan studi yang dilakukan di Kabupaten Cilacap. Dalam studi kualitatif ini, pengumpulan data dilakukan melalui wawancara mendalam dengan 21 orang mantan TKI perempuan (yang sudah kembali ke daerah asal/desa tempat tinggal di Cilacap), dari tanggal 4 sampai dengan 14 Mei 2017, di tiga kecamatan yaitu Kecamatan Binangun, Maos, dan Kesugihan. Analisis data dilakukan berdasarkan tematema komponen penting dalam proses pengambilan keputusan mencakup alternatif atau pilihan tindakan (pilihan untuk bermigrasi/tidak bermigrasi dan pilihan negara tujuan), pengambil keputusan (aktor), dan tujuan yang ingin dicapai (motivasi untuk bermigrasi/bekerja di luar negeri).

\section{MIGRASI TKI PEREMPUAN UNTUK BEKERJA DI LUAR NEGERI}

Migrasi TKI untuk bekerja di luar negeri sudah terjadi sejak beberapa dekade yang lalu, sebelum kemerdekaan Indonesia dan masih tetap berlangsung sampai saat ini. Migrasi TKI ini terjadi baik secara spontan maupun yang diatur oleh pemerintah kolonial dan pemerintah Indonesia setelah kemerdekaan. Pada umumnya di negara tujuan TKI bekerja sebagai buruh perkebunan, buruh pada proyek-proyek pembangunan dan konstruksi, serta petani kecil (Aswatini, 2006). Pada masa pemerintahan kolonial Belanda pengiriman tenaga kerja ini juga dilakukan ke beberapa negara di bawah program rekrutmen kuli kontrak, yang ditujukan untuk mendapatkan tenaga kerja/buruh murah di perkebunan. Pengiriman tenaga kerja ini antara lain ke negara-negara Malaysia, Suriname, Kaledonia Baru, Kalimantan Utara (masuk dalam wilayah koloni Inggris), Cochin China, dan Queensland, Australia (Hugo, 2004).
Pada awalnya, sesuai dengan sifat pekerjaannya, mayoritas tenaga kerja yang dikirim sebagai kuli kontrak adalah laki-laki. Akan tetapi, pemerintah kolonial Belanda kemudian juga mengijinkan rekrutmen perempuan untuk bekerja sebagai kuli kontrak di perkebunan kopi di Sumatera (Breman, 1997). Selain bekerja di perkebunan, buruh perempuan ini dipekerjakan sebagai pembantu rumah tangga pada staf perkebunan berkebangsaan Eropa (Hosen dan Raharto, 2013). Setelah kemerdekaan Indonesia, sekitar tahun 1970-an, migrasi TKI untuk bekerja di luar negeri meningkat pesat dengan meningkatnya permintaan akan tenaga kerja laki-laki dari negaranegara Timur Tengah untuk dipekerjakan di proyekproyek pembangunan infrastruktur. Kondisi ini kemudian diikuti dengan terus meningkatnya permintaan akan tenaga kerja pembantu rumah tangga perempuan di negara-negera Timur Tengah, melebihi permintaan akan tenaga kerja laki-laki (Asis, 2005; Hugo, 2002).

Tabel 1 menunjukkan bahwa selama periode 19891994 (REPELITA V), dilihat dari wilayah penerima, pengiriman TKI perempuan yang lebih besar daripada laki-laki hanya wilayah Timur Tengah dan Afrika. Data untuk tahun 2013-2015 menunjukkan adanya penurunan proporsi pengiriman TKI perempuan dibandingkan laki-laki. Kondisi ini ditemukan di wilayah Timur Tengah dan Afrika, sedangkan untuk wilayah Asia Pasifik, Amerika, dan Eropa proporsi pengiriman TKI perempuan meningkat dibandingkan laki-laki. Jika dilihat menurut negara penerima TKI, pada periode 1989-1994 hanya pengiriman ke negaranegara Arab Saudi, Singapura, Brunei Darussalam, dan Hongkong yang menunjukkan jumlah TKI perempuan yang lebih besar dibanding laki-laki. Data untuk periode 2013-2015 menunjukkan bahwa ada pergeseran negara tujuan utama dalam migrasi TKI perempuan. Arus TKI ke Singapura dan Hongkong tetap didominasi perempuan, bahkan migrasi perempuan menjadi lebih penting dengan turunnya rasio jenis kelamin. Beberapa negara yang sebelumnya tidak menjadi tujuan utama migrasi TKI perempuan seperti Taiwan dan Kuwait pada periode 2013-2015 sudah menjadi negara yang penting sebagai tujuan TKI perempuan dengan rasio jenis kelamin masing-masing sebesar 38,0 dan 34,3. Sebaliknya, negara-negara seperti Arab Saudi, Malaysia, dan Brunei Darussalam menunjukkan peningkatan arus migrasi TKI laki-laki (rasio jenis kelamin di atas 100). 
Jurnal Kependudukan Indonesia | Vol. 12, No. 1, Juni 2017 | 39-54

Tabel 1. Rasio Jenis Kelamin Tenaga Kerja Indonesia (TKI) yang Dikirim ke Luar Negeri Antara Tahun 1989-1994 dan 2013-2015 Menurut Negara Tujuan

\begin{tabular}{|c|c|c|c|}
\hline Wilayah/Negara & $\begin{array}{c}\text { Jumlah TKI yang } \\
\text { dikirim ke luar negeri }\end{array}$ & Persen & $\begin{array}{c}\text { Rasio jenis } \\
\text { kelamin }\end{array}$ \\
\hline \multicolumn{4}{|l|}{ 1989-1994 } \\
\hline \multicolumn{4}{|l|}{ Wilayah } \\
\hline 1. Timur Tengah dan Afrika & 390.639 & 59,9 & 13,4 \\
\hline 2. Asia Pasifik & 237.368 & 36,4 & 143,3 \\
\hline 3. Amerika & 14.122 & 2,1 & $34.343,9$ \\
\hline 4. Eropa & 10.143 & 1,6 & $6.753,4$ \\
\hline Jumlah & 652.272 & 100,0 & 47,5 \\
\hline \multicolumn{4}{|l|}{ Negara } \\
\hline 1. Arab Saudi & 384.822 & 59,0 & 12,5 \\
\hline 2. Malaysia & 156.312 & 24,0 & 196,3 \\
\hline 3. Singapura & 48.896 & 7,5 & 68,9 \\
\hline 4. Amerika Serikat & 13.993 & 2,1 & $37.718,9$ \\
\hline 5. Brunei Darussalam & 10.205 & 1,6 & 13,3 \\
\hline 6. Taiwan & 7.888 & 1,2 & 704,1 \\
\hline 7. Belanda & 5.515 & 0,8 & $12.155,6$ \\
\hline 8. Hongkong & 5.304 & 0,8 & 46,7 \\
\hline 9. Jepang & 4.913 & 0,8 & 346,6 \\
\hline 10. Korea & 3.464 & 0,5 & 205,5 \\
\hline 11. Kuwait & 3.004 & 0,5 & $4.668,3$ \\
\hline 12. Uni Emirat Arab & 2.323 & 0,4 & 11,7 \\
\hline \multicolumn{4}{|l|}{$1994-2008$} \\
\hline \multicolumn{4}{|l|}{ Wilayah } \\
\hline 1. Timur Tengah dan Afrika & 2.847 .673 & 44,7 & - \\
\hline 2. Asia Pasifik & 3.476 .568 & 54,6 & - \\
\hline 3. Amerika & 18.338 & 0,3 & - \\
\hline 4. Eropa & 10.206 & 0,2 & - \\
\hline Jumlah & 6.372 .922 & 100,0 & 36 \\
\hline \multicolumn{4}{|l|}{$2013-2015$} \\
\hline \multicolumn{4}{|l|}{ Wilayah } \\
\hline 1. Timur Tengah dan Afrika & 276.268 & 22,7 & 42,9 \\
\hline 2. Asia Pasifik dan Amerika & 919.260 & 75,5 & 87,5 \\
\hline 3. Eropa & 22.248 & 1,8 & 494,5 \\
\hline Jumlah & 1.217 .776 & 100,0 & 77,6 \\
\hline \multicolumn{4}{|l|}{ Negara } \\
\hline Arab Saudi & 112.719 & 9,3 & 102,8 \\
\hline 2. Malaysia & 375.698 & 30,8 & 176,5 \\
\hline 3. Singapura & 87.230 & 7,2 & 19,7 \\
\hline 4. Amerika Serikat & 28.795 & 2,4 & $1.714,6$ \\
\hline 5. Brunei Darussalam & 32.878 & 2,7 & 174,5 \\
\hline 6. Taiwan & 241.512 & 19,8 & 38,0 \\
\hline 7. Belanda & 2.024 & 0,2 & $4.719,0$ \\
\hline 8. Hongkong & 92.141 & 7,6 & 3,0 \\
\hline 9. Jepang & 5.938 & 0,5 & $1.139,7$ \\
\hline 10. Korea & 32.723 & 2,7 & $3.980,2$ \\
\hline 11. Kuwait & 4.458 & 0,4 & 34,3 \\
\hline 12. Uni Emirat Arab & 70.086 & 5,7 & 11,6 \\
\hline 13. Negara-negara lain & 131.574 & 10,8 & 70,1 \\
\hline
\end{tabular}

Sumber: Hugo (1995) Tabel 4, untuk data tahun 1989-1994.

UN-ESCAP \& UN-ESCWA (2013). Tabel VI.2, untuk data tahun 1994-2008

Badan Pusat Statistik [BPS] (tanpa tahun).

Catatan: TKI bekerja tersebar di lebih kurang 170 negara (BNP2TKI, 2016). 
Meskipun jumlah TKI perempuan yang bekerja di luar negeri memperlihatkan penurunan, proporsinya masih tetap lebih besar dibandingkan TKI laki-laki. Ini disebabkan karena kesempatan kerja yang terbuka untuk perempuan jauh lebih besar, terutama untuk pekerjaan-pekerjaan di sektor non-formal di rumah tangga seperti pembantu rumah tangga (domestic workers), pengasuh anak (babysitter) dan penjaga orang tua (caregiver). Selain dari itu, biaya untuk kepergian ke luar negari lebih murah untuk tenaga kerja perempuan dibandingkan laki-laki (Raharto dkk., 2013). Terbukanya kesempatan kerja untuk TKI perempuan di luar negeri sangat dipengaruhi oleh pembangunan yang pesat dan tranformasi struktural yang terjadi di negara-negera tujuan. Pertumbuhan ekonomi dan meningkatnya kebutuhan hidup di negara-negara tersebut menjadi salah satu penyebab perempuan berpartisipasi dalam pasar kerja dan membangun karier di luar rumah. Hal ini menimbulkan kebutuhan akan pengganti peran mereka dalam urusan domestik (Asian Development Bank, 2006; Ooi, 2013; Kaur, 2013). Di samping itu, pekerjaan yang tidak membutuhkan keterampilan dan tingkat upah yang rendah ditinggalkan oleh perempuan di negara tujuan, sehingga terbuka kesempatan untuk tenaga kerja migran (International Organization for Migration [IOM], 2010). Dalam kasus migrasi TKI perempuan, upah yang rendah untuk ukuran negara tujuan masih lebih tinggi dibandingkan upah di daerah asal, sehingga menjadi faktor penarik yang penting dalam proses migrasi ini (Aswatini, 2002; UN-ESCAP \& UN-ESCWA, 2013). Di negara-negara asal tenaga migran perempuan seperti Indonesia dan Filipina, pengiriman tenaga kerja ini juga sudah menjadi bagian penting dalam perencanaan ekonomi dengan tujuan untuk mengurangi tekanan pengangguran dan meningkatkan devisa dari luar negeri, berupa remitansi yang dikirim oleh TKI ke daerah asalnya (Hugo, 2004; Raharto, 2007). Oleh karena itu, pemerintah Indonesia mengeluarkan beberapa peraturan berupa Undangundang dan Peraturan Presiden untuk mengatur pengiriman TKI serta membentuk badan khusus yaitu Badan Nasional Penempatan dan Perlindungan Tenaga Kerja Indonesia (BNP2TKI) sebagai pelaksana kebijakan di bidang penempatan dan perlindungan TKI di luar negeri (Palmer, 2016; UN-ESCAP \& UNESCWA, 2013). Selain untuk mengatasi masalah pengangguran, strategi pemerintah dalam pengiriman TKI ke luar negeri bertujuan untuk mendapatkan sumber devisa luar negeri (Palmer, 2016).

Banyak faktor yang berpengaruh terhadap keputusan $\mathrm{TKI} /$ calon TKI untuk bermigrasi mencari pekerjaan di luar negeri serta memilih negara tertentu sebagai tujuannya. Sampai saat ini, pengiriman TKI untuk bekerja di luar negeri masih didominasi oleh tenaga berpendidikan dan berkeahlian rendah (low education and skill). Berdasarkan jabatan pekerjaannya, sebagian besar juga bekerja sebagai pekerja rumah tangga dan pengasuh anak/pengurus orang tua (caregiver/ caretaker), yang karena sifat pekerjaannya sangat erat terkait dengan tingginya proporsi TKI perempuan (Lampiran 1). Alasan utama untuk memilih bekerja di luar negeri juga didominasi oleh alasan ekonomi, baik sebagai faktor pendorong di daerah asal maupun faktor penarik di negara tujuan (Aswatini, 2002; UN-ESCAP \& UN-ESCWA, 2013). Akan tetapi, kedudukan dan peran perempuan dalam rumah tangga juga menunjukkan pentingnya faktor non-ekonomi dalam pertimbangan dan keputusan untuk bekerja di luar negeri.

\section{PENDEKATAN DALAM ANALISIS PENGAMBILAN KEPUTUSAN MIGRASI}

Pengambilan keputusan dapat diartikan sebagai proses pemilihan satu kegiatan (a course of action) dari dua atau lebih alternatif kemungkinan untuk sampai pada satu solusi terhadap satu permasalahan (Al-Tarawneh, 2012; McGrew \& Wilson, 1982). Dalam konteks yang sangat umum, Fox, Cooper \& Glasspoll (2013 dalam Tabor, 2014) mendefinisikan 'pengambilan keputusan' sebagai satu proses atau satu rangkaian proses yang menghasilkan satu pilihan dari beberapa kemungkinan alternatif. Hasil pemilihan dari beberapa alternatif tersebut dapat diartikan sebagai 'keputusan'.

Suatu keputusan dipahami sebagai solusi yang dicapai oleh pengambil keputusan, diarahkan oleh satu tujuan yang ingin dicapai, sebagai reaksi terhadap adanya suatu kebutuhan dan keinginan untuk memenuhi kebutuhan tersebut (Jabes, 1982; Harrison, 1981 dalam Al-Tarawneh, 2012). Oleh karena itu, suatu keputusan merupakan kondisi akhir dari suatu proses dinamis, yaitu proses pengambilan keputusan. Dalam proses pengambilan keputusan, pengambil keputusan (aktor) akan mengidentifikasi permasalahan, mengklarifikasi tujuan-tujuan yang spesifik, mempelajari kemungkinan-kemungkinan untuk dapat mencapai tujuan-tujuan, dan mengakhiri proses tersebut dengan satu pilihan tindakan yang jelas (Jabes, 1982; McGrew dan Wilson, 1982; Baker dkk., 2001 dalam AlTarawneh, 2012). Dari proses yang dilalui ini dapat disimpulkan adanya tiga komponen penting yang harus diperhatikan dalam analisis pengambilan keputusan, yaitu adanya alternatif atau pilihan tindakan, adanya pengambil keputusan (aktor), dan adanya tujuan yang ingin dicapai (motivasi untuk diambilnya keputusan tersebut). 
Dalam analisis pengambilan keputusan migrasi TKI perempuan ini dapat diasumsikan bahwa perempuan mempunyai pilihan untuk tidak bekerja (hanya mengurus rumah tangga), bekerja di dalam negeri, dan bekerja di luar negeri. Bagi perempuan yang memutuskan untuk bekerja di luar negeri juga ada pilihan untuk memilih negara tertentu sebagai tujuannya. Sebagai individu, dengan mengabaikan peran dan kedudukan perempuan dalam keluarga, perempuan dapat diasumsikan sebagai pengambil keputusan (aktor) tunggal yang akan mempertimbangkan keuntungan dan manfaat yang akan didapatnya dengan bekerja di luar negeri. Akan tetapi, kedudukan dan peran perempuan di rumah tangga dalam hubungan dengan anggota rumah tangga laki-laki (ayah, suami, dan saudara laki-laki) menjadi pertimbangan bahwa perempuan bukan pengambil keputusan (aktor) tunggal dalam proses ini. Dengan demikian, selain keuntungan dan manfaat pribadi yang diharapkan untuk didapat, ada pertimbangan untuk keuntungan dan manfaat yang akan didapat keluarga.

Analisis dalam studi migrasi internasional sebagian besar berkembang berdasarkan pendekatan ekonomi (Aswatini, 2011). Pendekatan ekonomi ini didasarkan pada prinsip dasar bahwa keputusan untuk bekerja di luar negeri tergantung pada perbedaan pendapatan dan biaya migrasi. Pendekatan ini memang sangat bermanfaat untuk memahami proses migrasi tenaga kerja, tetapi tidak tepat untuk menganalisis migrasi pengungsi yang terpaksa bermigrasi serta anggota keluarga yang ikut bermigrasi (Bodvarsson \& Van den Berg, 2013). Dalam konteks pengambilan keputusan untuk bermigrasi, pendekatan ekonomi ini didasarkan pada prinsip-prinsip rasional bahwa hasil akhir yang diharapkan adalah hasil maksimal dari suatu pilihan (keputusan) untuk bermigrasi atau tidak, dan untuk memilih satu negara tujuan dibandingkan negaranegara lainnya. Dua pendekatan yang didasarkan pada prinsip-prinsip rasional ini antara lain dapat dipahami dari pendekatan ekonomi mikro neoklasik (neoclassical microeconomic) (Todaro, 1976; 1989; Brettell \& Hollifield, 2000) dan pendekatan ekonomi baru migrasi (the new economic of migration) (Stark, 1984; Stark \& Bloom, 1985; Massey dkk., 1993). Pendekatan pertama mengasumsikan bahwa migrasi merupakan hasil dari proses pengambilan keputusan rasional individu calon migran dengan memperhitungkan biaya dan keuntungan dari migrasi untuk invidu tersebut di masa yang akan datang (Massey dkk., 1993; Faist, 1997 dalam Brettell \& Hollifield, 2000). Pendekatan ini mengabaikan keuntungan atau kerugian yang didapat keluarga atau anggota keluarga lainnya yang tinggal di rumah, dan tidak bermigrasi (Bodvarsson \& Van den Berg, 2013).

Pendekatan kedua berdasarkan asumsi bahwa keputusan untuk bermigrasi bukan merupakan keputusan rasional individu calon migran, tetapi merupakan keputusan keluarga yang terdiri dari beberapa individu anggota keluarga, dan biasanya anggota keluarga laki-laki lebih kuat perannya dalam keputusan akhir yang diambil. Dengan demikian, secara rasional keuntungan yang akan didapatkan keluarga dan anggota keluarga lainnya yang menjadi tujuan utama (Bodvarsson \& Van den Berg, 2013). Pendekatan kedua ini tampaknya lebih cocok untuk negara-negara berkembang dengan pembagian peran dalam keluarga yang masih kuat antara laki-laki dan perempuan.

\section{PENGAMBILAN KEPUTUSAN DALAM MIGRASI TKI PEREMPUAN UNTUK BEKERJA DI LUAR NEGERI: KASUS KABUPATEN CILACAP}

\section{Migrasi TKI untuk bekerja di luar negeri}

Kabupaten Cilacap, merupakan kabupaten di Jawa Tengah yang terbanyak mengirim TKI untuk bekerja di luar negeri dan merupakan kabupaten ketiga terbanyak mengirim TKI di tingkat nasional, setelah Kabupaten Lombok Timur dan Indramayu (Lampiran 1). Data tahun 2016 menunjukkan bahwa Kecamatan Binangun, Maos dan Kesugihan merupakan tiga kecamatan, dari total 24 kecamatan yang mengirim TKI terbesar untuk bekerja di luar negeri. Ketiga kecamatan ini menjadi lokasi penelitian dalam studi kualitatif/mendalam untuk memahami proses pengambilan keputusan untuk bekerja di luar negeri. Sebagian besar TKI dari Kabupaten Cilacap terdiri dari perempuan $(80,8$ persen $)$ dan sebagian besar bekerja di Taiwan (51,6 persen). Tiga negara tujuan lainnya adalah Malaysia, Singapura, dan Hongkong (Tabel 2). 
Tabel 2. Jumlah TKI Migran dari Kabupaten Cilacap menurut Negara Tujuan dan Jenis Kelamin, Tahun 2016

\begin{tabular}{|c|c|c|c|c|c|c|c|c|c|c|c|}
\hline \multirow{3}{*}{ No. } & \multirow{3}{*}{ Kecamatan } & \multicolumn{8}{|c|}{ Negara tujuan } & \multirow{2}{*}{\multicolumn{2}{|c|}{ Total }} \\
\hline & & \multicolumn{2}{|c|}{ Taiwan } & \multicolumn{2}{|c|}{ Malaysia } & \multicolumn{2}{|c|}{ Singapura } & \multicolumn{2}{|c|}{ Hongkong } & & \\
\hline & & $\mathrm{L}$ & $\mathrm{P}$ & $\mathrm{L}$ & $\mathrm{P}$ & $\mathrm{L}$ & $\mathrm{P}$ & $\mathrm{L}$ & $\mathrm{P}$ & $\mathrm{L}$ & $\mathrm{P}$ \\
\hline 1. & Binangun & 51 & 233 & 33 & 10 & - & 22 & - & 41 & 84 & 306 \\
\hline 2. & Maos & 40 & 169 & 30 & 9 & - & 56 & - & 53 & 70 & 287 \\
\hline 3. & Kesugihan & 21 & 107 & 52 & 25 & - & 74 & - & 65 & 73 & 271 \\
\hline 4. & $\begin{array}{l}20 \text { kecamatan } \\
\text { lainnya }\end{array}$ & 218 & 1.206 & 317 & 283 & - & 446 & - & 404 & 535 & 2.339 \\
\hline 5. & Total & 330 & 1.715 & 432 & 327 & - & 598 & - & 563 & 762 & 3.203 \\
\hline
\end{tabular}

Catatan: L=Laki-laki. P=Perempuan

Sumber: Dinas Sosial, Tenaga Kerja dan Transmigrasi [Dinsosnakertrans] Kabupaten Cilacap (2016).

Pada tahun 2016, seperti yang terdaftar pada Dinas Sosial, Tenaga Kerja dan Transmigrasi (Dinsosnakertrans) Kabupaten Cilacap, terdapat sebanyak 25.486 orang pencari kerja di Kabupaten Cilacap, dengan proporsi pendidikan terbesar SLTA (66,5 persen). Dari jumlah tersebut hanya sejumlah 7.391 orang yang dapat ditempatkan. Sekitar 64,2 persen ditempatkan untuk bekerja di luar negeri dan sisanya ditempatkan di dalam negeri, baik di dalam maupun di luar Kabupaten Cilacap. Kondisi ini menunjukkan bahwa kesempatan kerja yang terbuka di luar negeri sangat penting dalam mengatasi masalah pengangguran di Kabupaten Cilacap. Namun demikian, data ini juga mungkin hanya berdasarkan pendaftaran dari mereka yang memang ingin bekerja di luar negeri.

Dibandingkan dengan kabupaten lainnya di Provinsi Jawa Tengah, Kabupaten Cilacap bukan merupakan wilayah dengan proporsi penduduk miskin yang tinggi, meskipun proporsi penduduk miskin di wilayah ini pada tahun 2015 (14,39 persen) lebih tinggi dari proporsi untuk Provinsi Jawa Tengah (13,58 persen). Kabupaten dengan proporsi penduduk miskin tertinggi di Provinsi Jawa Tengah pada tahun 2015 adalah Kabupaten Brebes (19,79 persen) dan terendah adalah Kota Semarang $(4,97$ persen). Banyaknya TKI asal Kabupaten Cilacap yang bekerja di luar negeri tampaknya memiliki kontribusi dalam mengurangi penduduk miskin. Keadaan ini juga dapat dipahami dari besarnya remitansi yang dikirim TKI di luar negeri ke Kabupaten Cilacap yang pada tahun 2015 mencapai kurang lebih 408,5 milliar rupiah (Dinsosnakertrans Kabupaten Cilacap, 2016), jauh lebih besar dari Produk Domestik Regional Bruto (PDRB) Kabupaten Cilacap yang berjumlah 99,5 milliar rupiah pada tahun yang sama (BPS Kabupaten Cilacap, 2016, Tabel 11.1).
Secara total, selama tahun 2011-2015 sebanyak 27.144 tenaga kerja dari Kabupaten Cilacap ditempatkan untuk bekerja di luar negeri dan 87 persen diantaranya adalah tenaga kerja perempuan (BPS Kabupaten Cilacap, 2016, Tabel 3.2.3).

\section{Proses pengambilan keputusan}

Proses pengambilan keputusan untuk bekerja di luar negeri di kalangan TKI/calon TKI perempuan mencakup tiga komponen penting yaitu (i) adanya pilihan kegiatan: tidak bekerja dan sepenuhnya mengurus rumah tangga, bekerja di dalam negeri, dan bekerja di luar negeri, termasuk pilihan negara tujuan; (ii) pengambil keputusan (aktor) yang sangat menentukan dalam keputusan akhir; dan (iii) adanya motivasi yang mendasari keputusan yang diambil. Dari pendalaman data di Kabupaten Cilacap juga ditemukan bahwa untuk TKI perempuan yang masih berusia muda sebetulnya juga tersedia pilihan untuk melanjutkan sekolah. Namun demikian, kondisi ekonomi dan ketidakmampuan orang untuk membiayai pendidikan menghilangkan pilihan tersebut, seperti yang dinyatakan oleh responden Yun.

Yun berusia 25 tahun, lulus Sekolah Menengah Pertama (SMP) ketika berusia 14 tahun. Lulus SMP Yun bekerja di Jakarta di tempat fotokopi selama tiga tahun, kemudian bekerja di Singapura ketika berumur 17 tahun selama dua tahun, dan dilanjutkan bekerja di Taiwan selama tiga tahun. Sebetulnya Yun ingin melanjutkan sekolah ke tingkat Sekolah Lanjutan Tingkat Atas (SLTA), tetapi karena menyadari ketidakmampuan orang tua untuk membiayai pendidikannya Yun memilih untuk bekerja seperti yang diceritakannya: 
Yun. Sebenarnya pengen sekolah lah, orang pas waktu SMP, guru pas ambil ijazah bilang 'Kenapa ga sekolah kan ada piagam ini. Kan kamu juara-juara ini'. Ya, gimana lagi bapak ga ada biaya, kasihanlah. Nanti orang tua gimana biayainnya, daripada nyusahin orang tua, mending kerja aja lah. Udah langsung ke Jakarta. Alhamdulillah dua hari ke depan langsung berangkat.

Pernikahan pada usia muda juga menjadi salah satu faktor yang berpengaruh terhadap migrasi TKI perempuan, seperti pengalaman responden Umi, yang pernah bekerja di Arab Saudi dan Taiwan. Umi berumur 38 tahun dan berpendidikan SLTA. Ketika lulus sekolah Umi akan dinikahkan orang tuanya dan karena belum siap untuk menikah, Umi pergi bekerja ke Arab Saudi bersama saudara (budenya). Berikut adalah kutipan wawancara dengan Umi:

T (pewawancara): Dulu kan di Arab kan 2 tahun ya, tapi waktu itu nggak kepikiran balik lagi ke Arab?

J (Umi): Nggak, kan waktu itu saya memang bukan karena mau kerja apa, saya kan mau sekolah. Melarikan diri ya, jadi saya mau sekolah kek gitu....

Iya dulu mau masuk Akper [Akademi Perawat], udah jual tanah itu pak. Itu kan dijual buat sekolah saya, malah mau dinikahkan, nggak mau, akhirnya saya itu (pergi bekerja ke Arab).

Jum, berusia 42 tahun, berpendidikan SMP dan pengalaman kerja beberapa kali di Singapura, juga menyatakan tekadnya untuk bekerja di luar negeri karena orang tuanya (ayah) tidak mau menyekolahkan ke tingkat SLTA, dan bahkan akan dinikahkan.

Jum. Dulu disuruh nikah, cuma saya gak mau. Pokoknya kalo saya belum punya rumah sendiri saya gak mau nikah. Saya juga abis pulang dari Singapur, saya pengen sekolah lagi pengen lanjutin, tapi ya udahlah terlanjur udah sakit hati, ya udah cari uang aja, aku ingin membuktikan kepada bapakku aja gitu bahwa aku gak dibantu bapak aku insya Allah aku bisa, gitu aja sih. Gak ada keinginan lain tuh, gak ada yang dipikirkan, itu cuma sakit hati sama bapak saya, saya sampe gak disekolahin.
Bagi TKI migran perempuan (yang saat wawancara sudah merupakan mantan TKI), mengurus rumah tangga memang tidak menjadi pilihan yang tersedia. Pada umumnya mereka pergi bekerja ke luar negeri karena tekanan kebutuhan ekonomi, sebab pendapatan suami dirasakan tidak mencukupi untuk memenuhi kebutuhan hidup keluarga.

Suy, sebagai contoh, berusia 38 tahun dan hanya berpendidikan SD, sudah pernah bekerja dua kali di Arab Saudi. Dia pertama kali bekerja di Jeddah selama dua tahun dan kemudian di Mekkah selama empat tahun. Ketika berangkat bekerja ke luar negeri pertama kali Suy sudah memiliki dua orang anak, usia 6 tahun dan 19 bulan. Kutipan wawancara dengan Suy menjelaskan tentang tidak adanya pilihan baginya untuk hanya tinggal di rumah mengurus rumah tangga sebagai berikut:

Suy. Ya perginya itu ceritanya mau bantuin suami, biar gak itu, berat. Bantu ekonomi lah. Karena kalu di desa kan ya kurang ...jadi ya dikitdikit untuk bantu suami gitu. Waktu itu kerjanya (suami) bikin tegel di sini, kerja ikut orang.

Kitanya tujuannya ingin bantu suami dan besarin anak lah gimana orang ekonominya itu kurang, ya jadi ya udah lah...

Pengalaman Dar juga menjelaskan tidak ada pilihan untuk hanya mengurus rumah tangga, seperti yang dinyatakannya:
Dar. ...melihat orang, bukannya bukannya ini orang sukses, kepengen ini itu enggak. Pokoknya kita harus kita bisa merubah apa ya...merubah nasib jangan begini terus, nanti masa depan anak nanti gimana kalau mengandalkan suami yang kadang suami seminggu kerja, seminggu enggak gimana ya selanjutnya yo tiap hari dipikir habis sholat kepikir (untuk bekerja di luar negeri).

Dar, berumur 53 tahun, hanya berpendidikan SD tidak tamat dan suaminya buta huruf, memiliki pengalaman kerja selama 18 tahun di Arab Saudi. Pertama berangkat bekerja ke Arab Saudi, Dar berumur 24 tahun dan sudah memiliki tiga orang anak yang ketika ditinggalkannya untuk bekerja diurus oleh ibunya (nenek dari anak-anak tersebut) dan adik-adik Dar. 
Arab Saudi menjadi negara tujuan yang penting pada awal tahun 1970-an bagi TKI perempuan untuk bekerja di luar negeri dan mencapai proposi yang besar (dibandingkan TKI laki-laki) pada tahun 1980-an (UNESCAP \& UN-ESCWA, 2013). Pengalaman pertama bekerja di luar negeri ini juga membuka wawasan perempuan tentang berbagai kesempatan kerja yang tersedia, beban kerja dan besaran gaji di negara-negara lain karena selama bekerja mereka juga berhubungan dengan tenaga-tenaga kerja dari negara-negara lainnya dan saling bertukar informasi. Selain itu, dalam proses rekrutmen melalui perusahaan pengerah TKI, mereka mendapatkan informasi-informasi tentang kesempatan kerja di luar negeri. Lebih lanjut, informasi tentang upah, kondisi kerja, dan budaya yang dibawa pulang TKI ke daerah asal masing-masing juga membuka wawasan dan menjadi salah satu faktor yang memengaruhi pilihan negara tujuan bagi calon TKI maupun mantan TKI yang merencanakan untuk kembali bekerja di luar negeri. Oleh karena itu, biasanya untuk keberangkatan kedua kalinya, calon TKI perempuan lebih memilih untuk tidak bekerja di Arab Saudi, tetapi di negara-negara Asia seperti Singapura, Hongkong, dan Taiwan. Beban kerja yang tidak seberat pekerjaan sebagai pembantu rumah tangga di Arab Saudi dan gaji lebih besar tampaknya menjadi faktor yang cukup berpengaruh untuk menentukan pilihan negara tujuan ini.

Dar, sebagai contoh, menggambarkan bagaimana beratnya kerja di Arab Saudi:

Dar. Kerja di Saudi walaupun sekeras apa tetap kuat. Padahal kerjanya ya Allah, kalau lagi makan-makan bu ...hari Kamis sama hari apa ya, pasti mengadakan pesta.

Capenya bu, kerja di luar. Capek banget yang namanya ngepel kaya lapangan terbang dari ujung sana sampai sana.

Kalau aku diajak sama majikan (ke rumah saudaranya), bukannya di sana seneng-seneng, bantu di dapur namanya kerjaan kaya kapal pecah, sampai beres baru bawa pulang, Pokoknya pembantu ya Allah kalau di sana... kalau nyuci halaman juga sampai licin... bener lebar halamannya orang sana.
Umi menjelaskan alasan memilih Taiwan sebagai negera tujuan kedua, setelah selesai kontrak kerja di Arab Saudi:

T (Pewawancara): Kan tadi ke Arab, nah sekarang proses ke Taiwan gimana, kok milih Taiwan?

J (Umi): Kan di Taiwan itu kerjanya jompo, ngurus jompo gitu. Terus kerjanya nggak berat, gitu. Jadi saya pilihnya Taiwan, jadi gitu. Ya alhamdulillah, ya masing-masing kan beda-beda. Alhamdulillah saya sholat, apa, wiridan satu hari pun bisa gitu, karena cuman jaga jompo aja.

Yun yang pernah bekerja di Singapura dan Taiwan menjelaskan alasan memilih Taiwan setelah selesai kontrak kerja di Singapura:

Yun. Pengen mencoba yang...kan
katanya Taiwan gajinya lebih. Kalau
di Singapura kalau diperhitungkan
kan kurang. Apa sih kalau pengen
ngebangun rumah ya kaya gini masih
kurang, belum lagi keperluan sehari-
hari, jadi kepikiran ambil Taiwan aja.

Inisiatif untuk bekerja di luar negeri tampaknya lebih banyak berasal dari diri calon TKI perempuan karena mempertimbangkan kondisi ekonomi keluarga. Namun, untuk sampai pada keputusan 'berangkat bekerja ke luar negeri' anggota keluarga laki-laki, terutama orang tua masih sangat berperan dalam menentukan keputusan terakhir. Perempuan di Indonesia memang sudah mempunyai peran yang signifikan dalam menyumbang pendapatan untuk keluarga (Aswatini, 2002), tetapi hal ini tidak berarti mereka juga bebas menentukan keputusan sendiri (aktor) dalam migrasi untuk bekerja di luar negari. Keluarga tetap merupakan unit terpenting dalam proses pengambilan keputusan ini. Oleh karena itu, proses pengambilan keputusan untuk bekerja di luar negeri bagi calon TKI perempuan lebih tepat dijelaskan dengan pendekatan ekonomi baru migrasi the new economics of migration). Dalam menjelaskan migrasi tenaga kerja perempuan, pendekatan ini berangkat dari pemahaman bahwa tugas-tugas perempuan dalam mengurus rumah sama pentingnya dengan partisipasinya dalam pekerjaan yang menghasilkan upah, (Radcliffe 1986a, 1986b dalam Hugo, 1992). 
Dalam kasus migrasi TKI perempun di Kabupaten Cilacap, proses pengambilan keputusan melibatkan anggota keluarga, terutama suami dan orang tua. Inisiatif untuk bekerja di luar negeri umumnya berasal dari diri perempuan sendiri, baik perempuan yang belum ataupun sudah menikah. Meskipun suami dan/atau orang tua terlibat dalam proses pengambilan keputusan, untuk beberapa kasus, mereka bukanlah penentu keputusan akhir. Pada awalnya mereka masih menahan (tidak mengijinkan), akan tetapi akhirnya menyetujui keinginan anak atau istri mereka. Ini mungkin disebabkan karena tekanan kebutuhan ekonomi yang tidak dapat dipenuhi orang tua (ayah) atau suami sehingga tampaknya laki-laki terbentur pada ketidakberdayaan untuk 'menahan', padahal sebenarnya nilai budaya di desa belum berubah, yaitu laki-laki adalah pencari nafkah utama dalam keluarga. ${ }^{2}$ Selain itu, kesempatan kerja yang tersedia di luar negeri, terutama untuk tenaga kerja berkeahlian rendah (low skill) memang lebih terbuka untuk perempuan dibandingkan laki-laki. Selanjutnya, biaya migrasi juga lebih murah untuk TKI perempuan. Kutipan wawancara dengan beberapa wanita mantan TKI migran menggambarkan proses tersebut.

Tin, berusia 37 tahun, lulusan SMEA. Ketika pergi bekerja untuk pertama kali ke Singapura, Tin berumur 20 tahun dan belum menikah. Berikut kutipan wawancara yang menjelaskan pengambil keputusan dalam proses migrasi pertamanya:

\section{T (Pewanacara): Kenapa Bu bekerja} ke luar negeri?

$\boldsymbol{J}$ (Tin): Ya pertama ingin cari pengalaman, kedua pengen kerja aja, supaya pengen bantu orang tua lah.

\section{T: Tapi diomongin dulu sama orang tua?}

$J$ : Ya saya kepengen kerja, boleh gak boleh saya kepengen kerja, gitu...

\section{$T$ : Langsung boleh sama orang tua} atau...?

$J: \quad Y a$ nantilah nanti, baru lulus sekolah maksudnya istirahat di rumah atau cari kerja di rumah, gak lah saya mau keluar negeri aja gitu, terus orang tua terserah lah kalo itu keinginan kamu terserah, gitu
Untuk keberangkatan kedua kalinya bekerja ke luar negeri, Tin sudah menikah dan memiliki anak berumur 3 tahun dan suami langsung mengijinkannya:

\section{T: Terus pulang kerja menikah atau berangkat lagi baru menikah?}

\section{J: Pulang menikah terus punya anak itu...ya, terus umur 3 tahun lah kurang lebih saya pergi lagi}

\section{T: Nah terus gimana tuh ngomong sama suami?}

J: Mas saya mau bantu Mas nya, terus dianya kan setuju ...yang penting kan tujuannya bantu suami gitu untuk masa depan anak-anak, untuk kita lah keluarga, gitu.

Penjelasan lainnya berasal dari Tur yang berumur 30 tahun dan berpendidikan tamat SMP. Pada usia 16 tahun, Tur bekerja di Singapura dari tahun 2003 hingga 2006, kemudian kembali ke desa dan menikah di tahun yang sama. Pada tahun 2008, Tur kembali bekerja ke Hongkong meninggalkan anak berumur 1 tahun 2 bulan. Petikan wawancara berikut adalah penjelasan Tur tentang ijin kepada suami untuk bekerja di Hongkong:

T (pewawancara): Mbak, kan menikah tahun 2006 pergi ke Hongkong tahun 2008, berarti kan dalam perkawinan dengan dia, itu gimana? Memang diijinkan atau mba maksa?

$\boldsymbol{J}$ (Tur): Engga, ga maksa, diijinin sih Ya cuma langsung bilang aku pingin kerja lagi ke luar negeri. Kamu itu kan kalau kerja pilih-pilih, jadi aku bilang namanya anak kan makin gede makin besar biayanya, kalau kerjanya kaya gini terus gimana ntar gitu. Ya aku kerja saja ke luar negeri, gitu buat kebutuhan kita gitu.

T: Boleh...?

J: Bolehin...

\footnotetext{
${ }^{2}$ Hasil wawancara dengan Koordinator Program Pendidikan dan Pemberdayaan SDM di bawah Nahdatul Ulama/NU
} 
Dari beberapa kutipan di atas dan wawancara lainnya dapat disimpulkan bahwa pilihan untuk bekerja di luar negeri juga sangat dipengaruhi oleh faktor ekonomi, kesulitan untuk memenuhi kebutuhan, dan kesempatan untuk mendapatkan upah yang lebih tinggi di luar negeri. Akan tetapi, kebutuhan ini tidak semata-mata kebutuhan sehari-hari. Keberhasilan TKI perempuan yang sudah pernah bekerja di luar negeri dan mampu membangun rumah menjadikan 'membangun rumah' sebagai motif yang sangat penting memengaruhi keputusan untuk bermigrasi dan bekerja di luar negeri. Selain itu, keinginan untuk menyekolahkan anak ke jenjang pendidikan yang lebih tinggi memotivasi perempuan untuk bekerja berulang-ulang di luar negeri. Kondisi tersebut dapat dipahami dari beberapa kutipan berikut ini.

Nar, sebagai contoh, berumur 42 tahun dan berpendidikan SD. Pernah bekerja di pabrik di Cilacap ketika berumur 18 tahun dan memutuskan untuk bekerja di luar negeri karena alasan berikut:

\section{T (Pewawancara): Kalau mbak Nar gimana sampe mutusin mau kerja (di luar negeri) gitu?}

$\boldsymbol{J}$ (Nar): Kalo saya mikirnya kurs [nilai tukar uang asing dengan rupiah], kerjanya sama capeknya, gajinya rendah, di sana tinggi gitu. Udah, mendingan di sana aja (di luar negeri). Kita kan diharuskan kerja, kita kan orang gak punya, gak tergantung sama orang tua, kalo kita gak kerja kan gak punya apa-apa.

T: Tapi kalo gak kerja sebenarnya orang tua masih bisa kan buat hidup aja?

J: Ya kan kita butuhnya gak makan aja, ya buat biaya sekolah ya. Kalo menurut saya, setelah ini kan kita menikah harus ada rumah menurut saya.

Dar menjelaskan pemanfaatan pendapatannya dari bekerja di Saudi Arabia selama 18 tahun untuk membangun rumah dan menyekolahkan empat orang anaknya hingga tingkat SMA. Dar sudah bercerai pada tahun 2004 dan harus membiayai keempat anaknya dengan bekerja di Arab selama 10 tahun. Saat ini, Dar memiliki rumah yang cukup mewah yang dibangun di tanah orang tuanya. Dar menjelaskan motivasinya untuk bolak-balik bekerja di Saudi Arabia sebagai berikut:
T (Pewawancara): Nah kemudian setelah kembali ke sini gimana sih kehidupan Ibu?

J (Dar): Alhamdulillah, tapi ya memang bener-bener membanting tulang kerja keras banget, pengen punya uang, pengen punya rumah yang bener...

T: Kemudian apa saja yang sudah ibu dapat?

J: Engga lah bu gak dapet apa-apa, cuma ini saja (rumah ini). Lainnya kan untuk menyekolahkan anak sampai SMP, 4 sampai STM, SMA berat banget $b u$.

\section{T: Terakhir ibu bekerja 6 tahun di Saudi nggak balik-balik?}

\section{J: Lama banget sampai berat banget sih, cita-cita padahal sudah gak betah banget pengen pulang. Ya kerja lagi sampai 6 tahun yang terakhir gak pulang untuk mencari uang bikin rumah.}

Uraian di atas menunjukkan bahwa proses pengambilan keputusan TKI perempuan untuk bekerja di luar negeri tidak melibatkan pilihan-pilihan lain yang tersedia, selain bekerja di luar negeri. Proses pengambilan keputusan juga melibatkan anggota keluarga inti (orang tua dan suami) tetapi tampaknya mereka tidak menjadi penentu keputusan akhir yang menghasilkan 'keputusan untuk migrasi, bekerja di luar negeri'. Inisiatif untuk bekerja umumnya datang dari anak atau istri, sementara orang tua atau suami hanya menyetujui. Ini mungkin disebabkan mereka (orang tua/suami) juga tidak dapat memenuhi kebutuhan anak/istri, seperti kebutuhan untuk melanjutkan sekolah, memperbaiki/membuat rumah, dan menyekolahkan anak.

\section{KESIMPULAN}

Migrasi TKI untuk bekerja di luar negeri sudah terjadi sejak lama. Pada awalnya, mereka dibawa oleh pemerintah kolonial Belanda dan Inggris untuk dipekerjakan di perkebunan-perkebunan. Pada saat itu keterlibatan perempuan hanya sebagai pembantu rumah tangga pada staf perkebunan berkebangsaan Eropa. Setelah kemerdekaan Indonesia, permintaan akan TKI laki-laki untuk bekerja di luar negeri terus meningkat diikuti permintaan TKI perempuan, terutama sebagai pembantu rumah tangga di negaranegara Timur Tengah. Peningkatan permintaan TKI 
perempuan dan kesempatan kerja yang terbuka untuk perempuan juga terus meningkat, sehingga di beberapa negara tujuan seperti Taiwan, Hongkong, dan Singapura, jumlah TKI perempuan bahkan melebihi laki-laki. Selain itu, terjadi pergeseran negara tujuan utama TKI perempuan. Negara-negara Timur Tengah, terutama Saudi Arabia tidak lagi menjadi tujuan utama. Ini merupakan hal yang menarik untuk dicermati, bagaimana proses pengambilan keputusan dalam migrasi TKI perempuan ini menyangkut pilihanpilihan kegiatan, siapa yang terlibat dan menentukan pilihan tersebut serta apa motivasi atau tujuan dari keputusan yang diambil.

Dari analisis data-data kualitatif berdasarkan wawancara mendalam dengan mantan TKI perempuan (yang sudah kembali ke desanya di Cilacap) terungkap bahwa sebenarnya pilihan-pilihan kegiatan yang tersedia untuk perempuan tidak sepenuhnya dapat dipertimbangkan karena umumnya perempuan bekerja (bahkan untuk beberapa kasus mereka harus bekerja) karena alasan kebutuhan ekonomi. Faktor-faktor nonekonomi, seperti faktor sosial budaya, tidak terlalu berperan dalam menentukan pilihan akhir tersebut. Contohnya, pemahaman yang sudah berakar dalam masyarakat tentang peran laki-laki dan perempuan, yaitu laki-laki sebagai pencari nafkah utama dan kepala rumah tangga yang seharusnya bekerja untuk memenuhi kebutuhan rumah tangga dan perempuan sebagai ibu rumah tangga yang bertanggung jawab terhadap 'pengurusan rumah tangga',

TKI perempuan, baik yang belum maupun sudah menikah, juga sudah lebih memiliki kebebasan dalam menentukan pilihan untuk bekerja ke luar negeri dan negara pilihannya. Orang tua dan/atau suami tidak terlalu berperan dalam menentukan keputusan akhir dan hanya memberi persetujuan. TKI perempuan juga tampaknya sangat rasional untuk memilih negara tujuan, terutama untuk keberangkatan kerja kedua kali dan seterusnya, dengan mempertimbangkan beban kerja serta pendapatan/gaji. Ini juga didasarkan pada pengalaman mereka sendiri serta melihat pengalamanpengalaman mantan TKI perempuan yang sudah kembali ke desanya dengan sukses.

Pilihan perempuan untuk bekerja di luar negeri juga sangat ditentukan oleh kebutuhan ekonomi keluarga dan bukan sekedar kebutuhan pribadi perempuan. Kebutuhan keluarga seperti biaya sekolah anak, adik dan memperbaiki rumah orang tua atau rumah mereka (untuk yang sudah menikah) merupakan faktor yang sangat penting menjadi pertimbangan. Kepasifan suami dan orang tua dalam menentukan keputusan akhir dalam migrasi TKI perempuan ini didasarkan pada ketidakmampuan orang tua dan suami untuk memenuhi kebutuhan ekonomi seperti yang diinginkan anak ataupun istri, selain memang terbukanya kesempatan kerja yang lebih luas untuk perempuan bekerja di luar negeri dibanding laki-laki, khususnya di daerah penelitian di Kabupaten Cilacap, meskipun dalam posisi pekerjaan di sektor informal. Keadaan ini juga menunjukkan sudah terjadinya beberapa perubahan sosial dalam masyarakat di daerah asal migran TKI perempuan di Kabupaten Cilacap. Perubahan-perubahan ini terutama yang mencakup peran perempuan dalam keluarga, yang tidak lagi terfokus pada pengurusan rumah tangga dan anak, tetapi semakin pentingnya peran perempuan dalam mendukung kondisi ekonomi rumah tangga. Keadaan ini selanjutnya juga memengaruhi kemampuan perempuan untuk mengambil keputusan sendiri, yang terbaik untuk dirinya dan keluarganya dalam memanfaatkan kesempatan kerja yang terbuka di luar negeri.

\section{DAFTAR PUSTAKA}

Al-Tarawneh, H. A. (2012). The main factors beyond decision making. Journal of Management Research, 4(1:E18), 1-23. doi:10.5296/ jmr.v4i1.1184

Asian Development Bank. (2006). Workers' remittance flows in Southeast Asia. The Philippines: Asian Development Bank.

Asis, M. M. B. (2005). Recent trends in international migration in Asia and the Pacific. Asia Pacific Population Journal, 20(3), 15-38.

Aswatini. (2002). Indonesian female labour migrants: Experiences working overseas (A case study among returned migrants in West Java). Journal of Population, 8(1), 40-63.

(2006). Migrasi tenaga kerja internasional di Indonesia: Pengalaman masa lalu, tantangan masa depan. Dalam A. B. Lapian (Ed.), Sejarah dan dialog peradaban: Persembahan 70 tahun Prof. Dr. Taufik Abdullah. Jakarta: LIPI Press.

(2011). Migrasi tenaga kerja Indonesia dalam pasar kerja global (Orasi pengukuhan profesor riset). Lembaga Ilmu Pengetahuan Indonesia, Jakarta

Badan Nasional Penempatan dan Perlindungan Tenaga Kerja Indonesia [BNP2TKI]. (2015). Penempatan dan perlindungan tenaga kerja Indonesia tahun 2013 [Data].

Badan Pusat Statistik [BPS]. (tanpa tahun). Jumlah TKI menurut kawasan/negara penempatan dan jenis kelamin 2013-2015 [Data]. Diakses dari https://www.bps.go.id/linkTabelStatis/print/id/180 8 
BPS Kabupaten Cilacap. (2016). Kabupaten Cilacap dalam angka 2016. Cilacap: BPS Kabupaten Cilacap.

Bodvarsson, O. O., \& Van den Berg, H. (2013). The economics of immigration: Theory and policy, doi:10.1007/978-1-4614-2116-0

Boyd, M., \& Grieco, E. (2003, 1 Maret). Women and migration: Incorporating gender into international migration theory. Diakses dari http:// www.migrationpolicy.org/article/women-andmigration-incorporating-gender-internationalmigration-theory

Breman, J. (1997). Menjinakkan sang kuli: Politik kolonial pada awal abad Ke-20. Jakarta: Pustaka Utama Grafiti.

Brettell, C. B., \& Hollifield, J. F. (2000). Introduction. Dalam C. B. Brettell \& J. F. Hollifield (Ed.), Migration theory: Talking across disciplines (hal. 1-26). New York: Routledge.

Dinas Sosial Tenaga Kerja dan Transmigrasi [Dinsosnakertrans] Kabupaten Cilacap. (2016). Data remitansi/pengiriman uang TKI dari luar negeri tahun 2010-2016 [Data].

. (2016). Jumlah, jenis kelamin dan negara tujuan TKI migran dari Kabupaten Cilacap tahun 2016 [Data].

Fawcett, J. T., \& De Jong, G. F. (1981). Reasons for moving and migration behaviour. Dalam National migration surveys $X$ : Guidelines for analysis (hal. 109-131). Bangkok: UN-ESCAP.

Hosen, M. N., \& Raharto, A. (2013). Indonesian domestic workers overseas: Their position and protection in the global labour market. Dalam D. Hoerder \& A. Kaur (Ed.), Proletarian and gendered mass migrations: A global perspective on continuities and discontinuities from the 19th to the 21st centuries (hal. 385-404). Leiden: Koninklijke Brill NV.

Hugo, G. (1992). Women on the move: Changing patterns of population movement of women in Indonesia. Dalam S. Chant (Ed.), Gender and migration in developing countries (hal. 174-196). London and New York: Belhaven Press.

(1995). Labour export from Indonesia: An overview. ASEAN Economic Bulletin, 12(2), 275298.

(2002). Women's international labour migration. Dalam K. Robinson \& S. Bessell (Ed.), Women in Indonesia: Gender, equity and development (hal. 158-178). Singapore: Institute of Southeast Asian Studies.

(2004). International migration in Southeast Asia since World War II. Dalam A. Ananta \& E. N. Arifin (Ed.), International migration in Southeast Asia (hal. 28-70). Singapore: ISEAS Publication.
International Labour Organization [ILO]. (2015). Labour and social trends in Indonesia 2014-2015: Strenghtening competitiveness and productivity through decent work. Jakarta: ILO Country Office for Jakarta.

International Organization for Migration (IOM). (2010). Migrasi tenaga kerja dari Indonesia: Gambaran umum migrasi tenaga kerja Indonesia di beberapa negara tujuan di Asia dan Timur Tengah. Jakarta: IOM Indonesia

Jabes, J. (1982). Individual decision making. Dalam A. G. McGrew \& M.J. Wilson (Ed.), Decision making approaches and analysis (hal. 53-59). Manchester: Manchester University Press.

Kaur, A. (2013). Shifting geographies of migration in Southeast Asia: Continuity and change in proletarian and gendered migration, dalam D. Hoerder \& A. Kaur (Ed.), Proletarian and gendered mass migrations: A global perspective on continuities and discontinuities from the 19th to the 21st centuries (hal. 317-364). Leiden: Koninklijke Brill NV.

Massey, D. S., Arango, J., Hugo, G., Kouaouci, A., Pellegrino, A., \& Taylor, J. E. (1993). Theories of international migration: A review and appraisal. Population and Development Review, 19, 431-466.

McGrew, A. G., \& Wilson, M. J. (1982). Introduction. Dalam A. G. McGrew \& M. J. Wilson (Ed.) Decision making approaches and analysis (hal. 112). Manchester: Manchester University Press.

Ooi, K. G. (2013). From Amah-chieh to Indonesian maids: A comparative study in the context of Malaysia circa 1939s-1990s. Dalam D. Hoerder \& A. Kaur (Ed.), Proletarian and gendered mass migrations: A global perspective on continuities and discontinuities from the 19th to the 21st Centuries (hal. 405-426). Leiden: Koninklijke Brill NV.

Palmer, W. (2016). Indonesia's overseas labour migration programme, 1969-2010. Leiden: Koninklijke Brill NV.

Pusat Penelitian Pengembangan dan Informasi BNP2TKI. (2015). Data penempatan dan perlindungan tenaga kerja Indonesia tahun 2014 (Periode 1 Januari - 31 Desember) [Data].

. (2016a). Data penempatan dan perlindungan TKI periode November tahun 2016 [Data].

(2016b). Data penempatan dan perlindungan tenaga kerja Indonesia tahun 2015 [Data].

Raharto, A. (2007). Indonesian labor migration: Issues and challenges. International Journal on Multicultural Societies, 9(2), 219-235. 
Raharto, A., Noveria, M., Romdiati, H., Fitranita, Malamassam, M. A., \& Hidayati, I. (2013). Indonesian labour migration: Social cost and families left behind. Dalam Valuing the social cost of migration: An exploratory study (hal.19-71). Bangkok: UN Women.

Stark, O. (1984). Migration decision making: A review article. Journal of Development Economics, 14, 251-259.

Stark, O., \& Bloom, D. E. (1985). The new economic of labor migration. American Economic Review, 75, 175-178.

Suharso, Speare, A., Redmana, H. R., \& Husen, I. (1976). Rural urban migration in Indonesia. Jakarta: LEKNAS -LIPI.

Tabor, A. S. (2014). International migration decision making: The peculiar case of New Zealand (Tesis doktor, Victoria University of Wellington). Diakses dari http://researcharchive.vuw.ac.nz/xmlui/handle $/ 10063 / 3131$
Todaro, M. P. (1976). Internal migration in developing countries. Geneva: International Labour Office.

. (1989). Economic development in the third world. New York: Longman.

United Nations [UN]. (2016, 12 Januari). 244 millions international migrants living abroad worlwide, new UN statistics reveal. Diakses dari http://www.un.org/sustainabledevelopment/blog/2 016/01/244-million-international-migrants-livingabroad-worldwide-new-un-statistics-reveal/

UN-ESCAP \& UN-ESCWA. (2013). Inter-regional report on labour migration and social protection (E/ESCWA/SDD/2013/Technical Paper 2). Diakses dari http://www.unescap.org/sites/default/ files/SDD_PUB_ESCWA_SDD_2013_Technicalp aper2_E.pdf

United Nations Department of Economic and Social Affairs. (2016). International migration report 2015: Highlights. New York: United Nations. 
Pengambilan Keputusan Tenaga Kerja Indonesia (TKI) Perempuan...| Aswatini Raharto

Lampiran 1. Rangkuman Data Tentang Pengiriman Tenaga Kerja Indonesia ke Luar Negeri Tahun 2012-2015

\begin{tabular}{|c|c|c|c|c|c|}
\hline \multirow{2}{*}{\multicolumn{2}{|c|}{ Indikator dan level }} & \multicolumn{4}{|c|}{ Tahun dan jumlah } \\
\hline & & 2012 & 2013 & 2014 & 2015 \\
\hline \multicolumn{6}{|c|}{ Jumlah dan jenis kelamin } \\
\hline \multicolumn{6}{|c|}{ Nasional } \\
\hline- & Laki-laki & 214.825 & 235.170 & 186.243 & 108.965 \\
\hline- & Perempuan & 279.784 & 276.998 & 243.629 & 166.771 \\
\hline- & Total & 494.609 & 512.168 & 429.872 & 275.736 \\
\hline \multicolumn{6}{|c|}{ Jawa Tengah } \\
\hline - & Laki-laki & & 46.464 & 37.316 & 17.007 \\
\hline- & Perempuan & & 59.507 & 55.272 & 40.070 \\
\hline- & Total & & 105.971 & 92.590 & 57.077 \\
\hline \multicolumn{6}{|c|}{ Kabupaten/kota terbesar penempatan } \\
\hline \multicolumn{6}{|c|}{ TKI di luar negeri } \\
\hline- & Lombok Timur & 19.936 & 33.287 & 29.510 & 25.772 \\
\hline- & Indramayu & 28.524 & 28.410 & 25.521 & 19.064 \\
\hline- & Cilacap & 19.799 & 17.592 & 16.013 & 10.753 \\
\hline- & Cirebon (Kab) & 16.755 & 18.675 & 15.786 & 10.953 \\
\hline- & Lombok Tengah & 13.675 & 14.793 & 14.109 & 12.175 \\
\hline- & Cianjur & 12.266 & 14.639 & 11.311 & 5.437 \\
\hline \multicolumn{6}{|c|}{ Lapangan pekerjaan } \\
\hline \multicolumn{6}{|c|}{ Nasional } \\
\hline- & Formal & 258.411 & 285.297 & 247.610 & 247.610 \\
\hline- & Informal & 236.198 & 226.871 & 182.262 & 182,262 \\
\hline \multicolumn{6}{|c|}{ Jawa Tengah } \\
\hline- & Formal & & 56.870 & 51.156 & 25.369 \\
\hline- & Informal & & 49.101 & 41.434 & 31.708 \\
\hline \multicolumn{6}{|c|}{ Negara terbesar penerima TKI } \\
\hline \multicolumn{6}{|c|}{ Nasional } \\
\hline- & Malaysia & 134.069 & 150.250 & 127.827 & 97.635 \\
\hline- & Taiwan & 81.071 & 83.544 & 82.655 & 75.303 \\
\hline- & Saudi Arabia & 40.655 & 45.393 & 44.325 & 23.000 \\
\hline- & Hongkong & 45.478 & 41.769 & 35.050 & 15.322 \\
\hline- & Singapura & 41.556 & 34.655 & 31.680 & 20.895 \\
\hline- & United Emirat Arab & 35.888 & 44.505 & 17.962 & 7.619 \\
\hline \multicolumn{6}{|c|}{ Jawa Tengah } \\
\hline- & Malaysia & & 26.341 & 21.201 & 14.676 \\
\hline- & Taiwan & & 21.589 & 21.066 & 17.979 \\
\hline- & Singapura & & 13.143 & 12.603 & 8.674 \\
\hline- & Hongkong & & 13.444 & 12.120 & 5.545 \\
\hline- & Saudi Arabia & & 6.766 & 6.770 & 2.935 \\
\hline- & Korea Selatan & & 6.481 & 4.862 & 2.464 \\
\hline- & Brunei Darussalam & & 2.819 & 2.683 & 2.139 \\
\hline- & United Emirat Arab & & 2.831 & 1.327 & 646 \\
\hline- & Amerika Serikat & & 2.267 & 1.903 & 309 \\
\hline- & Jepang & & 1.060 & 819 & 73 \\
\hline- & Negara-negara lainnya & & 9.230 & 10.236 & 1.637 \\
\hline- & Total & & 105.971 & 95.590 & 57.077 \\
\hline
\end{tabular}

Sumber: 1). BNP2TKI (2015).

2). Pusat Penelitian dan Pengembangan Informasi BNP2TKI (2015)

3). Pusat Penelitian dan Pengembangan Informasi BNP2TKI (2016a)

4). Pusat Penelitian dan Pengembangan Informasi BNP2TKI (2016b) 
Jurnal Kependudukan Indonesia | Vol. 12, No. 1, Juni 2017 |39-54 